\title{
Toxicity and oviposition inhibitory effect of extract and powder of Momordica charantia leaf against Callosobruchus maculatus Fab. (Coleoptera: Chrysomelidae) on stored cowpea seed
}

\author{
Obembe, O. M. ${ }^{1}$ and Ojo, D. O. ${ }^{2^{*}}$ \\ ${ }^{1}$ Department of Plant Science and Biotechnology, Ekiti State University, PMB 5363, Ado-Ekiti, Nigeria. \\ ${ }^{2}$ Department of Zoology and Environmental Biology, Ekiti State University, PMB 5363, Ado-Ekiti, Nigeria. \\ ${ }^{*}$ Corresponding author. Email: entojo1@gmail.com
}

Copyright (@) 2018 Obembe and Ojo. This article remains permanently open access under the terms of the Creative Commons Attribution License 4.0, which permits unrestricted use, distribution, and reproduction in any medium, provided the original work is properly cited.

Received 9th March, 2018; Accepted 6th April, 2018

\begin{abstract}
The pulse beetles, Callosobruchus maculatus is a principal field-to store pest of cowpea in the tropics and at present synthetic insecticides constitute a major means of control. The insecticidal effect of ethanolic extracts and powders of Momordica charantia leaf against the cowpea beetle, Callosobruchus maculatus Fab. were carried out in the laboratory. The efficacy of powder and ethanolic extract of $M$. charantia leaf as toxicants against $C$. maculatus were investigated using contact toxicity and oviposition deterrence. The powders and extracts were applied at various dosages of $0.2,0.4,0.6$, and $0.8 \mathrm{~g}$ and $0.2,0.4,0.6$ and $0.8 \mathrm{ml}$ per $20 \mathrm{~g}$ of cowpea seeds. Beetle mortality was monitored for $96 \mathrm{~h}$. The mortality of the insect increased with increase in dosage and period of exposure. Within $24 \mathrm{~h}$ post treatment, $0.8 \mathrm{~g}$ dosage of the plant powder recorded the highest beetle mortality of $35 \%$ but its effect was not significantly $(p>0.05)$ different from that of 0.4 and $0.6 \mathrm{ml}$. At $96 \mathrm{~h}$ of post-treatment, all the dosages of the plant powders recorded above $75 \%$ insect mortality with $0.8 \mathrm{~g}$ of the powder achieving the highest insect mortality of $85 \%$ and its effect was not significantly $(\mathrm{p}<0.05)$ different from $0.2,0.4$ and $0.6 \mathrm{~g}$. At $96 \mathrm{~h}$ post treatment, $0.8 \mathrm{ml}$ of the extract achieved the highest mortality of $95 \%$ which was not significantly $(p<0.05)$ different from that of $0.6 \mathrm{ml}$. All dosages of the extract recorded up to $80 \%$ bruchid mortality within $96 \mathrm{~h}$ post treatment. At all treatment levels, insect mortality was significantly $(p<0.05)$ different from the control. It was observed that oviposition was reduced in both powder and extract treatments when compared to the control. The results show that both powder and extract of $M$. charantia were effective in controlling $C$. maculatus and could serve as alternative to over-dependence on synthetic insecticide for preservation of stored cowpea seeds against C. maculatus.
\end{abstract}

Key word: Callosobruchus maculatus, dosages, insecticidal, Momordica charantia, mortality, treatment.

\section{INTRODUCTION}

Cowpea, Vigna unguiculata (L.) Walp, is the most important food legume grown in the tropical and subtropical parts of Africa. It plays a critical role in the diets of many households in Africa, Latin America and Asia, providing nutrients that are deficient in cereals (Jackai and Daoust, 1986). Also, Okosun and Adedire (2010) reported that cowpea is an important leguminous crop, providing plant protein for human and animals' consumption.

Cowpea is susceptible to attack by Callosobruchus maculatus in storage. They cause heavy losses and physical damage. According to Oparaeke et al. (2000), yield losses in cowpea due to insect pests in Nigeria were estimated to be above $80 \%$. C. maculatus infestation causes direct damage to cowpea grains, causing loss of grains (Babarinde et al., 2015).

Currently, synthetic insecticides are the chief means of insect pests control both in the field and in storage (Ojo et al., 2018). They have shown efficacy against a wide range of pest species of agricultural crops. Chemical control is generally practiced by farmers for higher gains, but its 
injudicious utilization has created many problems. Sole reliance on chemical control leads to problems of pests resistance, resurgence of pests, pesticide residues, destruction of beneficial fauna (non-target) and environmental pollution, human poisoning, destruction of natural enemies of pests, crop pollination problem due to honey bee losses, domestic animal poisoning, contamination of livestock products, fish and wildlife losses and contamination of underground water and rivers (Ewete and Alamu1999; Asawalam and Adesiyan, 2001; Obembe, 2017). As yields are however generally low (Olatunde et al., 1991), sometimes total yield losses and crop failure occur (Singh and Jackai 1985) due to the activities of a wide spectrum of insect pests which ravage the crop in the field at different growth stages. Consequently, farmers spray their farms as many as eight to ten times during the growing season (Omongo et al., 1997).

As an alternative to the chemical insecticides, botanical insecticides have been discovered by researchers. Botanical insecticides are naturally occurring chemicals, extracted from plants which break down readily in the soil and are not stored in plant or animal tissue. Often, their effects are not long lasting as those of synthetic pesticides (Arong et al., 2011). Botanical insecticides are generally pest-specific and are relatively harmless to non-target organisms. These natural insecticides have proved to be effective, biodegradable, low cost, low technological base, selective and environmentally friendly (Obembe, 2017; Adededire et al., 2011; Ojo et al., 2018). Also, the possibility of insect developing resistance to botanical insecticide is less (Scott et al., 2005). Furthermore, plant extracts act as mortality agents, repellents, anti-feedants, attractants, oviposition deterrents and sterility agents (Lale, 2002).

Over 2000 species of plants are known to possess insecticidal activities (Sariah, 2010; Arong et al., 2011). Such plant materials include powders, water extracts, oil and wood ash from plants like Neem tree (Azadirachta indica), groundnuts (Arachid hypogea), nutmeg (Myristica fragrans) and coconut. Others are leaf extracts of ginger (Zingiber offficinale), garlic (Allium sativum), African Black Pepper (Piper guineensis) tobacco (Nicotiana tabacum), cashew (Anacardium occidental), (Ivbijaro, 1983; Grainger and Ahmed, 1988; Hall and Harman, 1991; Adedire et al., 2011; Musa et al., 2015; Babarinde et al., 2016).

$M$. charantia is popularly used in various systems of traditional medicine for various activities such as antidiabetic, antioxidant, antitumor, antiviral and analgestic (Shibu et al., 2017). An earlier study has revealed the insecticidal activity of $M$. charantia against mustered saw fly Athalia proxima (Kumar et al., 1979). Jayapal et al., (2012) also reported the larvicidal and pupicidal properties of the leaf crude extract of $M$. charantia against potent malarial vector, Anopheles stephensis. The present research aimed at evaluating the effectiveness of Momordica charantia leaf extracts and powders in the control of cowpea weevil, Callosobruchus maculatus.

\section{MATERIALS AND METHODS}

\section{Study area}

The study was conducted in Plant Science Department Laboratory, Ekiti State University, Ado Ekiti, Nigeria under prevailing atmospheric conditions of $28 \pm 2^{\circ} \mathrm{C}$ temperature and 70 to $75 \%$ relative humidity.

\section{Insect culture}

The initial culture of $C$. maculatus used for the experiment was obtained from local market in Iworoko Ekiti, Ekiti State, Nigeria, with naturally infested cowpea seeds. The insects were cultured at room temperature of $28 \pm 2^{\circ} \mathrm{C}$ and humidity of 70 to $75 \%$ inside a Kilner jar covered with muslin cloth to disallow the escape of the insect and as well disallow the entry of intruding insects that may act as parasitoid. The culture was maintained by replacing the damaged seeds with new un-infested seeds.

\section{Collection of plant materials and preparation of extracts}

Momordica charantia leaves were obtained from the Faculty of Science, Ekiti State University Ado Ekiti, Nigeria. The leaves were air-dried in the laboratory for two weeks in other to reduce the moisture content, so as to prevent moldiness. The air-dried leaves were ground into fine powder using an electric blender. The powder was stored in black cellophane bag until used for either extraction or powder bioassay with the bruchids. About 50 $\mathrm{g}$ of $M$. charantia powders was measured into thimbles and extracted using $95 \%$ ethanol in a Soxhlet apparatus at a temperature of 60 to $80^{\circ} \mathrm{C}$ for about 4 to 5 hours. The extract was exposed to slow blowing fan to remove any trace of ethanol and was thereafter poured into a bottle and stored in a refrigerator until needed for entomological bioassay.

\section{Effect of plant extracts and powder on weevil mortality}

Four dosages $(0.2,0.4,0.6$, and $0.8 \mathrm{ml})$ extract of $M$. charantia were mixed with $20 \mathrm{~g}$ of cowpea seed in separate Petri dishes. The cowpea grains were shaken vigorously to ensure uniform coating of the grains with the extracts. Ten males and ten females $C$. maculatus adult which were freshly emerged from the culture were released into the Petri dishes and covered in order to prevent the exit and entry of other insects. Also, 0.2, 0.4, 0.6 and $0.8 \mathrm{~g}$ of $M$. charantia leaf powder were mixed with $20 \mathrm{~g}$ of cowpea seeds in separate Petri dish and 10 males and 10 females adult $C$. maculatus which freshly emerged in the culture were released into Petri dish and covered tightly in order to prevent the entry and exit of insects. Ten males and ten females $C$. maculatus introduced in a Petri 
Table 1. Mortality (\%) of Callosobruchus maculatus exposed to different dosages of Momordica charantia powders.

\begin{tabular}{ccccc}
\hline \multirow{2}{*}{ Treatments (g) } & \multicolumn{4}{c}{ \% mortality in hours } \\
\cline { 2 - 5 } & $\mathbf{2 4}$ & $\mathbf{4 8}$ & $\mathbf{7 2}$ & $\mathbf{9 6}$ \\
\hline 0.2 & $17.50 \pm 4.27^{\mathrm{ab}}$ & $47.50 \pm 2.39^{\mathrm{b}}$ & $55.00 \pm 1.44^{\mathrm{b}}$ & $75.00 \pm 1.44^{\mathrm{b}}$ \\
0.4 & $27.50 \pm 4.27^{\mathrm{b}}$ & $50.00 \pm 2.04^{\mathrm{b}}$ & $60.00 \pm 2.04^{\mathrm{bc}}$ & $80.00 \pm 2.04^{\mathrm{b}}$ \\
0.6 & $32.50 \pm 2.39^{\mathrm{b}}$ & $55.00 \pm 1.44^{\mathrm{b}}$ & $62.50 \pm 2.39^{\mathrm{bc}}$ & $82.50 \pm 2.39^{\mathrm{b}}$ \\
0.8 & $35.00 \pm 3.23^{\mathrm{b}}$ & $57.52 \pm 2.39^{\mathrm{b}}$ & $67.50 \pm 2.39^{\mathrm{c}}$ & $85.00 \pm 1.44^{\mathrm{b}}$ \\
0.0 & $0.00 \pm 0.00^{\mathrm{a}}$ & $0.00 \pm 0.00^{\mathrm{a}}$ & $0.00 \pm 0.00^{\mathrm{a}}$ & $0.00 \pm 0.00^{\mathrm{a}}$ \\
\hline
\end{tabular}

Each value is mean \pm standard error of three replicates. Values followed by the same letter (s) are not significantly $(p>0.05)$ different from each other using New Duncan's Multiple Range Test.

Table 2. Mortality (\%) of Callosobruchus maculatus exposed to different dosages of Momordica charantia extract.

\begin{tabular}{ccccc}
\hline \multirow{2}{*}{ Treatments (ml) } & \multicolumn{4}{c}{ \% mortality in hours } \\
\cline { 2 - 5 } & $\mathbf{2 4}$ & $\mathbf{4 8}$ & $\mathbf{7 2}$ & $\mathbf{9 6}$ \\
\hline 0.2 & $30.00 \pm 3.23^{\mathrm{b}}$ & $55.00 \pm 3.23 \mathrm{~b}$ & $62.50 \pm 1.25 \mathrm{~b}$ & $80.00 \pm 2.04 \mathrm{~b}$ \\
0.4 & $32.50 \pm 2.39 \mathrm{bc}$ & $57.50 \pm 2.39 \mathrm{bc}$ & $65.00 \pm 1.44 \mathrm{~b}$ & $82.50 \pm 1.25 \mathrm{~b}$ \\
0.6 & $40.00 \pm 2.04 \mathrm{bc}$ & $60.00 \pm 2.04 \mathrm{bc}$ & $67.50 \pm 1.25 \mathrm{~b}$ & $87.50 \pm 2.39 \mathrm{bc}$ \\
0.8 & $47.50 \pm 2.39 \mathrm{c}$ & $70.00 \pm 2.04 \mathrm{c}$ & $77.50 \pm 1.25 \mathrm{c}$ & $95.00 \pm 1.44 \mathrm{c}$ \\
0.0 & $0.00 \pm 0.00^{\mathrm{a}}$ & $0.00 \pm 0.00^{\mathrm{a}}$ & $0.00 \pm 0.00^{\mathrm{a}}$ & $0.00 \pm 0.00^{\mathrm{a}}$ \\
\hline
\end{tabular}

Each value is mean \pm standard error of three replicates. Values followed by the same letter (s) are not significantly $(p>0.05)$ different from each other using New Duncan's Multiple Range Test.

dish with no extract or powder served as control for the experiment. Each dosage of the extract and powder bioassay and the control was replicated four times.

Mortality of the insects was observed and recorded at 24 $h$ interval. This was done by gently probing the insect with a sharp pin on the abdomen. Insect that did not react to the probing were considered dead (Adedire et al., 2011). This continued for 96 hours after which the survivors from the treated and untreated cowpea seeds were removed. Thereafter, the experiment was allowed to stay for another 3 days and data were collected on the number of eggs laid.

\section{Experimental design and data analysis}

Data obtained from all the parameters were subjected to one-way analysis of variance at $5 \%$ significant level and means were separated with New Duncan's Multiple Range Tests using SPSS version 17. In addition, data obtained from beetles' mortality were subjected to regression analysis to calculate the $\mathrm{LD}_{50}$ and $\mathrm{LD}_{95}$ of the powder and extract after 96 hours of application using probit analysis.

\section{RESULTS}

Percentage mortality of $C$. maculatus exposed to different concentration of $M$. charantia powder

Table 1 presents the toxic effects of $M$. charantia powder against $C$. maculatus. The mortality of the insect varied with the dosage of the plant powder and the period of exposure. Within 24 hours post treatment, $0.8 \mathrm{~g}$ dosage of the plant powder recorded the highest beetle mortality of $35 \%$ which was not significantly $(p>0.05)$ different from other treatments. At 72 hours of application, all the dosages of the plant powder recorded above $50 \%$ insect mortality with $0.8 \mathrm{~g}$ of the powder achieving the highest insect mortality of $67.5 \%$ and its effect was significantly $(p<0.05)$ different from $0.2 \mathrm{~g}$ dosage. All the dosages of the plant powders recorded above $70 \%$ mortality of the insect within 96 hours post treatment. Although, none of the dosages was able to achieve $100 \%$ mortality within 96 hours post treatment. The effects of the treatments were significantly $(p<0.05)$ different from the control throughout the period of exposure.

\section{Percentage mortality of $C$. maculatus exposed to different dosages of $M$. charantia extract}

Table 2 presents the toxicity of $M$. charantia extract against C. maculatus. At 24 hours post treatment, only $0.8 \mathrm{ml}$ of the extract was able to achieve above $45 \%$ mortality of the insect but its effect was not significant $(P>0.05)$ different from other treatment except $0.2 \mathrm{ml}$ dosage which recorded $30 \%$ bruchid mortality. At 72 hours after application, $0.8 \mathrm{ml}$ of extract achieved the highest insect mortality rate of 
Table 3. Lethal dose of Momordical charantia required to achieve 50 and $95 \%$ mortality of Callosobruchus maculatus within $96 \mathrm{~h}$ of application.

\begin{tabular}{lcccccc}
\hline Treatments & Slope \pm S.E & Intercept \pm S.E & $\mathbf{X}^{2}$ & LD $_{50}(95 \%$ FL) & LD $_{95}(95 \% F L)$ & Sig. \\
\hline Oil & $1.86 \pm 0.14$ & $-1.20 \pm 0.07$ & 88.235 & $4.44(3.67-5.99)$ & $9.76(6.42-10.64)$ & 0.0001 \\
Powder & $1.78 \pm 0.14$ & $-1.21 \pm 0.07$ & 87.102 & $5.00(4.01-7.36)$ & $11.31(7.73-16.26)$ & 0.0001 \\
\hline
\end{tabular}

S.E: standard error; $\mathrm{X}^{2}$ : Chi square; LD: lethal dose; FL: fiducial limit.

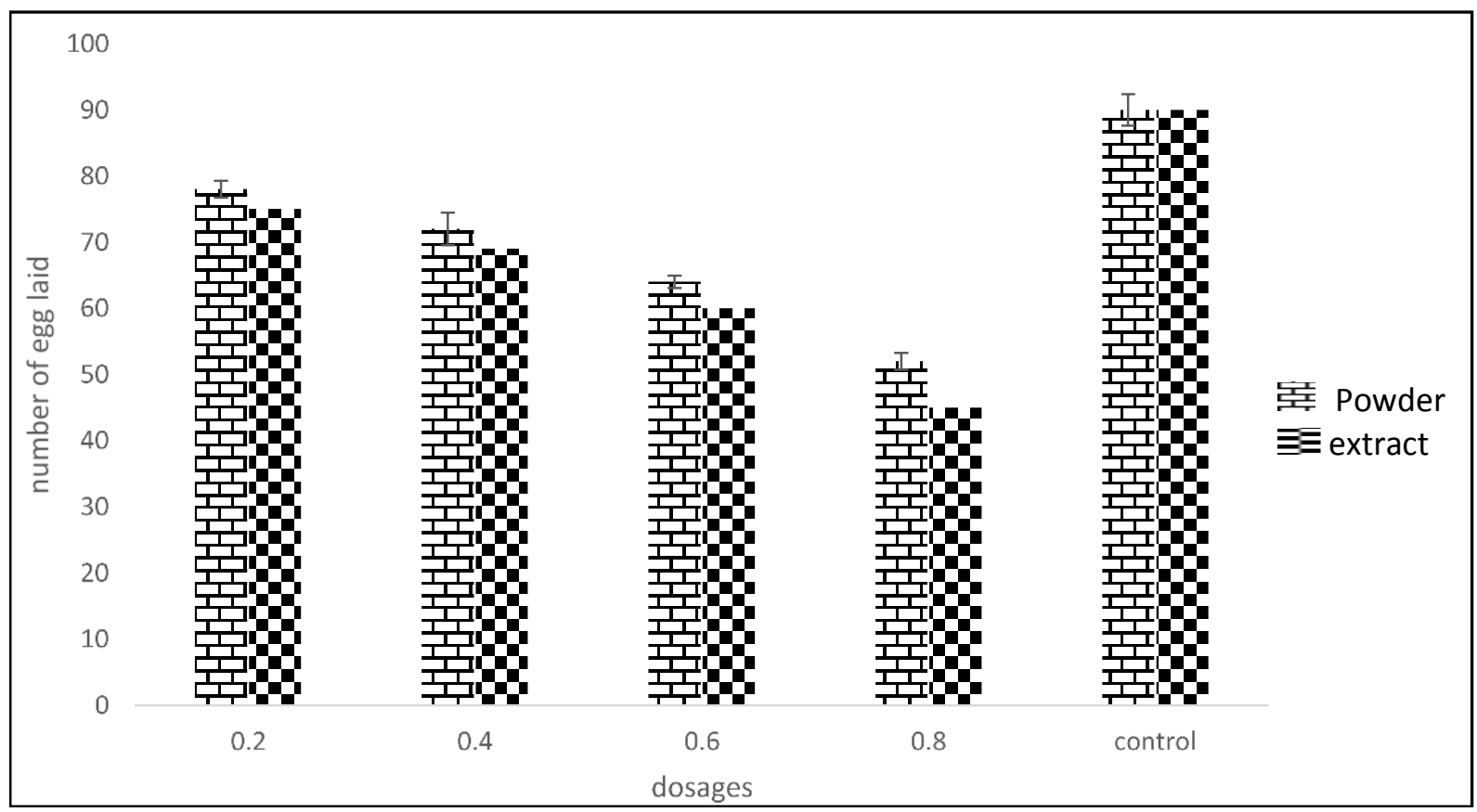

Figure 1. Number of egg laid by Callosobruchus maculatus exposed to powder and extract of Momordica charantia leaf.

$77.5 \%$ which was significantly $(p<0.05)$ different from other treatments. At 96 hours post treatment, $0.8 \mathrm{ml}$ of the extract achieved the highest mortality of $95 \%$. None of the dosages was able to achieve complete beetle mortality. All the extract dosages recorded up to $80 \%$ bruchid mortality within 96 hours post treatment which was significantly $(p<0.05)$ different from the control.

Lethal dosage of $M$. charantia required to achieve 50 and $95 \%$ mortality of $C$. maculatus within $96 \mathrm{~h}$ of exposure

The lethal dosages of $M$. charantia extract and powder required to achieve 50 and $95 \%$ mortality of the insect within 96 hours post treatment are presented in Table 3. The negative coefficient of the extract and powder indicated that the higher the dosage of the extract and powder, the higher the mortality of the insect. Also, chi square values that are greater than zero indicated the high level of relationship between the dosages of the treatments and the mortality of the insect. There was significant relationship between the mortality of the insect and dosages of extract and powder as the p-value of the calculated chi square was less than 0.05 . Only $4.44 \mathrm{ml}$ and $5.0 \mathrm{~g}$ dosages of the plant extract and powder were required to achieve $50 \%$ mortality of the beetle within 96 hours post treatment respectively. Furthermore, only 9.76 $\mathrm{ml}$ and $11.31 \mathrm{~g}$ of extract and powder of the botanical respectively were required to achieve $95 \%$ mortality of the insect within 96 hours post treatment.

\section{Effect of Extract and powder of $M$. charantia on $C$. maculatus oviposition}

Figure 1 presents the effect of extract and powder of $M$. charantia on adult $\mathrm{C}$. maculatus. The oviposition of the insect decreases as the dosages of the extract and powder increases. There were significant $(p<0.05)$ differences between the treatment and the control. There was significantly lowest oviposition of the bruchid on cowpea 
seeds treated with $0.8 \mathrm{ml}$ extract than the oviposition in other treatments. The extract was more effective than powder as lesser number of eggs were laid on cowpea seeds treated with the extracts than what was observed on the powder-treated seeds and the untreated control.

\section{DISCUSSION}

The result from this study shows that ethanolic extract and powder of Mormodica charantia leaf have insecticidal properties against Callosobruchus maculatus. This shows that M. charantia could successfully be used for the control of $\mathrm{C}$. maculatus. The extract from the plant were observed to be toxic on C. maculatus at various dosage of $(0.2,0.4$, 0.6 and $0.8 \mathrm{ml}$ ), and the leaf powder at various dosage of $(1 \mathrm{~g}, 2 \mathrm{~g}, 3 \mathrm{~g}$ and $4 \mathrm{~g})$. On oviposition inhibitory effect, M. charantia extract proves more effective than $M$. charantia powder. Previous researchers have demonstrated that extracts/oils are relatively efficacious against virtually all life stages of insects (Don-Pedro, 1998, Adedire, 2003). The results from this research are similar to the observation of Adedire et al. (2011), who obtained 97.50\% mortality of $\mathrm{C}$. maculatus in cowpea seeds treated with acetone extract from cashew kernels at $0.5 \% \mathrm{v} / \mathrm{w}$. Kayode and Obembe (2012) had also reported the effective protection of cowpea seeds against $C$. maculatus with aqueous extracts from seven tropical trees.

The finding is in conformity with the report of Yalamanchilli and Punukolu (2000) who observed that the oil from the leaves of Curcuma domestica could effectively protect cowpea seeds against $C$. chinensis at $2.0 \%$ concentration. Babarinde and Ewete (2008) also reported the toxicity and oviposition deterrence of three Khaya species against C. maculatus. The effectiveness of this botanical against $\mathrm{C}$. maculatus can be due to the presence of active constituents of the plant (Asawalam et al., 2007). Shibu et al., (2017) reported that the secondary metabolites of M. charantia are alkaloids, flavonoids, tanins, saponins and disogenin. Since both M. charantia leaf powder and extract were toxic against $C$. maculatus, either of them can serve as alternatives to over-dependence on synthetic insecticides and can be recommended for use by local farmers for the protection of cowpea seeds meant for consumption and sales.

\section{REFERENCES}

Adedire, C. O., Obembe, O. O., Akinkurolele, R. O., \& Oduleye, O. (2011). Response of Callosobruchus maculatus (Coleoptera: Chysomelidae: Bruchidae) to extracts of cashew kernels. Journals of Plant Diseases and Protection, 118(2), 7579.

Adedire, C. O. (2003). Use of Nutmeg Myristica fragans (Houtt.) Powder and Oil for the control of Cowpea storage Bruchids, Callasobruchus maculatus Fabricius. Journal of Plant Disease and Protection 109(2), 193-199.

Adedire, C. O., Obembe, O. M., Akinkurolere, R. O., \& Oduleye,
O. (2011). Response of Callosobruchus maculatus (Coleoptera: Chrysomelidae: Bruchidae) to extracts of cashew kernels, Journal of Plant Diseases and Protection, 118(2), 7579.

Arong, G. A., Oku, E. E., Obhiokhenan, A. A., Adetunji, B. A. \& Mowang, D. A. (2011). Protectant ability of Xylopia aethiopica and Piper guineense leaves against the cowpea bruchid Callosobruchus maculatus Fab. (Coleoptera: Bruchidae). World Journal of Science and Technology, 1(7), 1-19.

Asawalam, E. F., \& Dioko, U. J. (2001). Evaluation of toxicity of Dennetia tripetalla (Baker) F. and Curcuma longa L. rhizomes Against Cowpea Seeds Bruchid, Callosobucus maculatus F. (Coleoptera: Bruchidae). Agricultural Science Research Journal, 2(6), 308-311.

Asawalam, E. F., Emosaire, S. O., Ekeleme, F., \& Wokocha, R. C. (2007). Insecticidal effects of powdered parts of eight Nigerian Plant species against maize weevils Sitophilus zeamais Motschulsky (Coleoptera: Curculionidae). Journal of Entomology and Agricultural Food Chemistry, 6(11), 2526-2533.

Babarinde, S. A., \& Ewete, F. K. (2008). Comparative bioactivity of three Khaya species (Meliaceae) against Callosobruchus maculatus Fabricius (Coleoptera: Bruchidae). Journal of the Entomological Research Society, 10(1), 27-35.

Babarinde, S. A., Pitan, O. O. R., Olatunde, G. O., \& Ajala, M. O. (2015). First report of toxicity of Xylopia parviflora (A. Rich.) Benth (Annonaceae) root bark's essential oil against cowpea seed bruchid, Callososbruchus maculatus Fabricius (Coleoptera: Chrysomelidae: Bruchinae), Natural Product Research, 29(4), 349-352.

Babarinde, S. A., Sunnie-Ododo, M. O., Aknbi, W. B., Oyegoke, O. O., Tijani, R., \& Olaobaju, S. F. (2016). Comparative susceptibility of two developmental stages of hide beetle (Dermetses maculatus Degeer, 1774) to ginger (Zingiber officinale Roscoe) essesntial oil. Journal of Saudi Society for Agricultural Sciences. In press.

Don Pedro, K. N. (1998). Mode of action of fixed oils against egg of Callosobruchus maculatus F. Pesticide Science, 26, 107115.

Ewete, F. K., \& Alamu, O. T. (1999). Extracts of three mahogany species as grain protectants against Sitophilus zeamais Motschulsky (Coleoptera: Curculionidae). Journal of Tropical Forest Resources. 15, 22-29.

Grainge., M., \& Ahmed, S. (1988). Hand book of plants with pestcontrol properties. Resources System Institute, East-West Cennter, Honolulu, Hawaii, John Wiley and Son New York

Hall, J. S., \& Harman, G. E. (1991). Protection of stored legume seeds attack by storage fungi and weevils: mechanism of action of lipoidal and oil seed treatments. Journal of Crop protection. 10, 375-380.

Ivbiajaro, M. F. (1983). Groundnut oil as a protectant of maize damaged by the Weevil, Sitophilus zeamais (Motsch) Protection Ecology. 6: 267-270

Jackai, L. E. N., \& Daoust, R. A. (1986). Insect pest of cowpea. Annual Review of Entomology, 31, 95-105.

Jayapal, S., Kadarkarai, M., \& Kalimuthu, K. (2012). Larvicidal and pupicidal efficacy of Momordical charantia leaf extract and bacteria insecticide, Bacillus thuringiensis against malaria vector, Anopheles stephensis Liston. Journal of Biopesticide, 5(supplementary), 163-169.

Kayode, J., \& Obembe, O. M. (2012). Assessment of the insecticidal potential of the aquesous extracts of some Troical trees as protectant of Cowpea Seeds from Callosobrushus maculatus infestation. Biological Science Research Bulletting, 
28,39-47.

Kumar A., Tewari, G. D., \& Panday, N. D. (1979). Studies on antifeeding and insecticidal properties of bitter gourd (Momordica charantia Linn). Against mustered saw fly Athalia proxima Klug, Pesticides, 13(12), 9.

Lale, N. E. S. (2002). Stored Product Entomology and Acarology in Tropical Africa. Mole Publications, Maiduguri, Nigeria. p. 204.

Musa, A. K., Odunayo, A., \& Adeyeye, O. E. (2015). Effects of Initial Infestation Levels of Callosobruchus maculatus (F.) (Coleoptera: Chrysomelidae) on Cowpea and Use of Nicotiana tabacum L. Aqueous Extract as Grain Protectant. Journal of Northeast Agricultural University, 2(4), 1-6.

Obembe, O. M. (2017). Bio-insecticidal activity of Delonix regia oil extracts on Maize Weevils, Sitophilus zeamais (Motschulsky) (Coleoptera: Curculionidae). World Scientific News, 70(2), 86-96.

Ojo, D. O., Omotoso, O. T., \& Obembe, O. M. (2018). Effctiveness of the powders of Securidaca longependunculata (Fres.) as Bioinsecticides against Cowpea beetle, Callosobruchus maculatus (Fab.) (Coleoptera: Chrysomelidae). International Journal of Horticulture, 8(1), 17.

Okosun, O. O., Adedire, C. O. (2010). Potency of cowpea seed bruchid, Callosobruchus maculatus (Fabricius) [Coleoptera: Bruchidae], of African Nutmeg seed [Monodora myristica (Gaertn.) Dunal] extracted with different solvents. Niger. Journal Entomology, 27, 89-95.

Olatunde, G. O., Odebiyi, J. A., Chiang, H. S., \& Jackai, L. E. N. (1991). Identification of sources of resistance in cowpea, Vigna unguiculata L. Walp.to Clavigralla tomentosicollis. Stal. (Hemipera: Coreidae). Insect Science and its Application, 12(4), 455-461.

Omongo, C. A., Ogenga-Latigo, M. W., Kyamanywa, S., \& Adipala, E. (1997). The Effect of Seasons and Cropping Systems on The Occurrence of Cowpea Pests in Uganda. African Crop Science Society Proceedings, 3, 1111-1116.
Oparaeke, A. M., \& Amatobi, M. C. (2000). Insecticidal potentials of extracts of Garlic, Allium sativum L. bulb and African nutmeg Monodora myristica (Gaertn) Dunal seeds for insect pest control on cowpea. Entomological Society of Nigeria Occasional Publication, 32, 169-174.

Sariah, J. E. (2010). Enhancing cowpea (Vigna unguiculata L.) Production through insect pest resistant line in East Africa: PhD Thesis, University of Copenhagen.

Scott, I. M., Gangnon, N. Lesage, L. Philogene., B. J. R., \& Arnason, J. T. (2005). Efficacy of botanical insecticides from Piper species (Piperaceae) extracts for control of European chafer (Coleoptera scarabaeidae). Journal of Economic Entomology, 98, 845-855.

Shibu, N. J., Papiya, M. M., \& Nagaraju, G. (2017). Momordical charantia Linn as a medicinal plant: A review. World Journal of Pharmacy and Pharmaceutical Sciences, 7(1), 440-459.

Singh, S. R., \& Jackai, L. E. N. (1985). Insect pest of cowpea in Africa: their life cycle, economic importance and potential for control. In Singh, S. R., Rachie, K. O. (Eds.). Cowpea: Research, Production and Utilisation. Wiley, New York, pp. 217-232.

Yalamanchilli, R. P., \& Punukollu, B. (2000). Bio-efficacy studies on leaf oil of Curcuma domestica Valeton: Grain protectant activity. Journal of Medicinal and Aromatic Plant Sciences, 22(1), 715-716. 